\title{
TOXIC EFFECTS OF CYPERMETHRIN AND METHOMYL IN RATS
}

\author{
By \\ Mona A El-Harouny*, Sahar A El-Dakroory*, \\ Amal A EL-Bakary ${ }^{\star}$, \& Rehab Allah Ahmed ${ }^{\star \star}$ \\ Trom \\ Forensic Medicine and Clinical Toxicology Department, \\ Faculty of Medicine, Mansoura University, Egypt*. \\ Pathology Department, Faculty of Medicine, \\ Mansoura University, Egypt ${ }^{\star \star}$.
}

\begin{abstract}
Pesticides are widely used in agriculture and livestock production with potential health hazards. This study aimed to compare toxic effects of sub-lethal doses of cypermethrin and methomyl on rats and to investigate the spontaneous reversibility of these effects after discontinuation of exposure. Fifty adult male rats were randomly divided into three main groups. Group 1 (20 rats) was given cypermethrin orally as $5 \mathrm{mg} / \mathrm{kg}$ daily, group 2 (20 rats) was given methomyl orally as $1 \mathrm{mg} / \mathrm{kg}$ daily and the third group (10 rats) served as a control. After one month, half of animals (10 rats) from test groups (group 1a and group 2a) beside the control group were weighed and sacrificed.
\end{abstract}

The remaining rats were kept without treatment for 2 weeks then weighed and sacrificed (group $1 \mathrm{~b}$ and group $2 b)$. Serum aspartate transaminase, alanine transaminase and creatinine were determined. Histopathological examination of liver, kidney and testes from each rat were carried out. Results showed that both methomyl and cypermethrin induced reversible toxic effects to liver, kidney and testes. The present results should give continued emphasis to the correct handling and use of these insecticides at the recommended rates, dose and duration.

Keywords: cypermethrin, methomyl, rats, hepatotoxicity, nephrotoxicity, fertility, reversibility.

MANSOURA MEDICAL JOURNAL 


\section{INTRODUCSTION}

The use of cypermethrin (a synthetic pyrethroid), is increasing due to its high effectiveness, low toxicity to non-target organisms and easy bio-degradability (1). Methomyl, a widely used broad-spectrum carbamate insecticide, is classified by the Environmental Protection Agency (EPA) as class IB (Highly Hazardous) (2). Misuse of these compounds carries the risk of poisoning (3).

Some of the toxic actions of cypermethrin as well as methomyl have been reported earlier, but the comparative effect of oral administration of sub-lethal doses of both cypermethrin and methomyl on the liver, kidney and testes has not been investigated. So, this study aimed to compare toxic effects of sub-lethal doses of both pesticides on rats during oral administration and after cessation through clinical manifestations, histopathological examination of liver, kidney and testis as well as analysis of liver enzymes; serum aspartate transaminase (AST), alanine transaminase (ALT) and creatinine.

\section{MATERIAL \& METHODS}

This is an experimental compara- tive study of toxic effects of sublethal doses of cypermethrin and methomyl on rats. This study follows the ethical guidelines of Mansoura University Ethical Committee.

\section{Chemicals :}

The requisite amount of commercial cypermethrin \{Cypermethrin 10 $\%$ (Agrochemical, Jordan)\} and methomyl (Lannate 90, Acta Co.) was dissolved in $2 \mathrm{ml}$ distilled water.

\section{Animals :}

A total of 50 male albino rats weighing between $140-170 \mathrm{~g}$ $(151.05 \pm 6.73 \mathrm{~g})$ were used in this study. The rats were allowed to acclimate in the animal care facility for 7 days before the start of treatment. The animals were maintained in plastic cages with a controlled temperature of $25 \pm 2{ }^{\circ} \mathrm{C}$, a12h light-dark cycle and the rats were ad libitum fed with water and food.

Animal grouping and study design :

Animals were randomly divided into three main groups. Group 1 (20 rats) received oral cypermethrin as 5 $\mathrm{mg} / \mathrm{kg} /$ day (4), for one month. Group 2 (20 rats); received oral methomyl by gavage as $1 \mathrm{mg} / \mathrm{kg}$ (5), once daily

Vol. 43, No. 1 \& 2 Jan. \& April, 2014 
Mona A El-Harouny et al...

for one month. The third group (10 rats) served as a control.

All animals were weighed and observed daily for signs of treatment related effects during the 30 days treatments. Expected clinical manifestations are muscular weakness, swaying gait, respiratory distress and prostration (6). On the day 30 after beginning of treatment, half of the animals (10 rats) from each test group (groups 1a and 2a) beside the control group were weighed and sacrificed $2 \mathrm{~h}$ following the last dose by cervical dislocation. The remaining rats were kept without treatment for 2 weeks then weighed and sacrificed by cervical dislocation (groups $1 \mathrm{~b}$ and $2 b$ ).

Blood samples $(2 \mathrm{ml})$ from orbits were collected in $5 \mathrm{ml}$ polypropylene tubes, left $30 \mathrm{~min}$ to coagulate, centrifuged at $2000 \mathrm{rpm}$ and sera were tested for ALT, AST and creatinine. Liver, kidneys and testes of each rat were excised quickly and fixed in $10 \%$ formalin. For histopathological study, sections were cut in 4 micron thickness and stained with the routine Hematoxylin and Eosin stain and examined microscopically (Lica CX21 microscpoe).
Statistical analysis : Data were expressed as mean \pm S.D, median and range. Data were processed using MedCalc ${ }^{\circledR}$ program Version 8.1. Student's t-test was used for statistical analyses apart from weight. Nonparametric data (weight) was analyzed by Mann-Whitney $U$ test. Pvalues $<0.05$ were considered statistically significant.

\section{RESULTS}

Clinical manifestations and weight changes:

No clinical manifestation was induced by either cypermethrin or methomyl compared to control apart from decreased weight gain that was significant in methomyl group while it was insignificant in cypermethrin group. Weight increased after two weeks from cessation of administration of both cypermethrin and methomyl (Table 1).

Biochemical results (Table 1):

Both cypermethrin and methomyl increased AST and ALT significantly compared to control group with insignificant difference between test groups. After 2 weeks from cessation of administration, level of AST decreased significantly in methomyl group but insignificantly in cyper-

MANSOURA MEDICAL JOURNAL 
methrin group while level of ALT decreased insignificantly in both groups.

Creatinine increased significantly by both cypermethrin and methomyl compared to control with more significant increase in methomyl compared to cypermethrin group. Levels decreased significantly 2 weeks after cessation of cypermethrin administration but not in methomyl group.

\section{Histopathological results :}

Histopathological examination of control group showed normal liver, kidney and testes (Figure 1). Cypermethrin induced liver necrosis, disorganization of hepatic lamina, congested sinusoids, portal inflammation; lymphocytes and esinophils infiltrates with atrophy of bile ductules (Figures 2: a, b, c). These changes improved markedly 2 weeks after cessation of its administration (Figure $2 \mathrm{~d}$ ).
Concerning methomyl, it induced spotty necrosis, sinusoidal congestion, prominent Von Kupffer cells and spotty ballooning degeneration of the liver (Figures 3: a, b). Also these changes improved markedly 2 weeks after cessation of its administration (Figure $3 \mathrm{c}$ ).

Both cypermethrin and methomyl did not induce any observed histopathological changes in the kideny (Figures 4: a, b respectively).

As regards testes' examination, cypermethrin caused maturation arrest at spermatogonia and thick basement membrane (Figure 5 a), meanwhile methomyl induced maturation arrest at primary spermatocytes (Figure 6 a). These effects resolved 2 weeks after cessation of both cypermethrin and methomyl administration (Figures $5 b$ \& $6 b$ respectively). 
Mona A El-Harouny et al...

Table 1: Comparison between different groups regarding weight, liver enzymes (SGOT, SGPT) and creatinine.

\begin{tabular}{|c|c|c|c|c|c|c|}
\hline & \multirow[b]{2}{*}{$\begin{array}{l}\text { At the start of } \\
\text { sudy } \\
\text { (n: } 50)\end{array}$} & \multicolumn{3}{|c|}{ After onemonth } & \multicolumn{2}{|c|}{ After 15 month } \\
\hline & & $\begin{array}{l}\text { Control } \\
\text { (n: 10) }\end{array}$ & $\begin{array}{c}\text { G la (n:10) } \\
\text { (Cypemethrin) }\end{array}$ & $\begin{array}{l}\text { G2 2a (n: 10) } \\
\text { (Methonyl) }\end{array}$ & $\begin{array}{c}\text { Glb (n:10) } \\
\text { (Gypermethrin) }\end{array}$ & $\begin{array}{l}\text { G 2b (n:10) } \\
\text { (Mehonyl) }\end{array}$ \\
\hline \multicolumn{7}{|l|}{ Weight } \\
\hline Median (range) & $150(140-170)$ & $187.5(162-209)$ & $173(127-233)$ & $160(145-191)$ & $177(153-204)$ & $174.5(157-212)$ \\
\hline Two-tailed probabilitt & & $0.000]^{*}$ & $0.0010^{*}$ & $0.0180^{\star}$ & $<0.0001^{*}$ & $<0.000]^{\star}$ \\
\hline $\mathrm{Pl}$ & & & 0.1845 & $0.0011^{*}$ & 0.2210 & 0.3601 \\
\hline $\mathrm{P2}$ & & & & 0.2267 & & 0.9887 \\
\hline P3 & & & & & 0.0922 & $0.0345^{*}$ \\
\hline \multicolumn{7}{|l|}{ AST } \\
\hline Mean +SD & & $1600.00+3.80$ & $180.30 \pm 11.66$ & $188.50 \pm 15.12$ & $17330 \pm 6.8$ & $174.90 \pm 7.84$ \\
\hline $\mathrm{Pl}$ & & & $0.0012^{*}$ & $0.003^{*}$ & $<0.000]^{*}$ & $0.0009^{*}$ \\
\hline $\mathrm{P} 2$ & & & & 0.1681 & & 0.0988 \\
\hline P3 & & & & & 0.8176 & $0.0259 *$ \\
\hline \multicolumn{7}{|l|}{ ALT } \\
\hline Mean+SD & & $155 \pm 3.26$ & $28.38 \pm 7.12$ & $35.10 \pm 8.85$ & $30.90 \pm 5.40$ & $31.80 \pm 5.88$ \\
\hline $\mathrm{Pl}^{-}$ & & & $0.0004^{*}$ & $0.000]^{\star}$ & $<0.000]^{\star}$ & $0.0002^{*}$ \\
\hline $\mathrm{P} 2$ & & & & 0.0554 & & 0.7612 \\
\hline P3 & & & & & 0.3037 & 0.3339 \\
\hline \multicolumn{7}{|l|}{ Crentinine } \\
\hline Mean + SD & & $0.79 \pm 0.05$ & $1.05 \pm 0.05$ & $1.23 \pm 0.16$ & $1.13 \pm 0.07$ & $1.11 \pm 0.11$ \\
\hline $\mathrm{Pl}$ & & & $<0.0001^{*}$ & $<0,0001^{*}$ & $<0,0001^{*}$ & $<0,000]^{*}$ \\
\hline $\mathrm{P} 2$ & & & & $0.0033^{*}$ & & 0.6543 \\
\hline $\mathrm{P} 3$ & & & & & $0.0142^{*}$ & 0.1275 \\
\hline
\end{tabular}

Two-taled probobility is for companison with we gight at beginining of study.

Pl is for compaing all test groups with control group atere one month

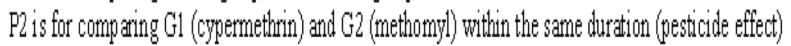

P3 is for comp ding subgroups a (atter one moonth) and b (ateet 1.5 months) (time effect) 


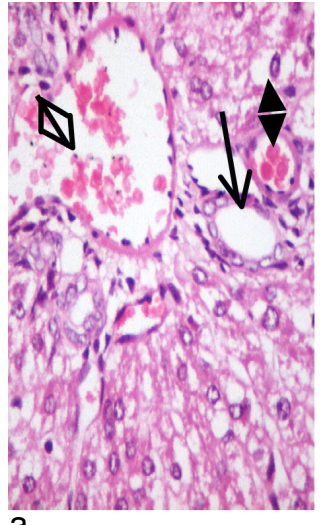

a

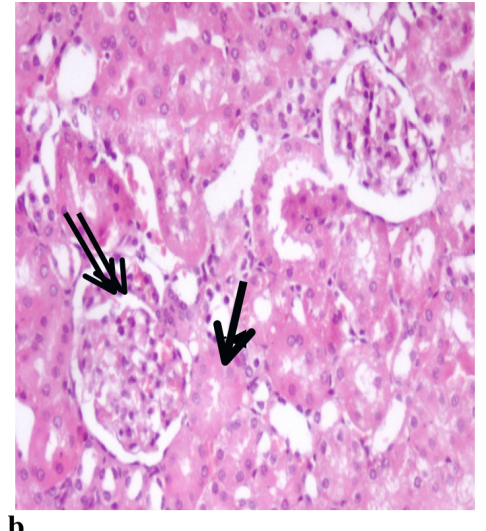

b

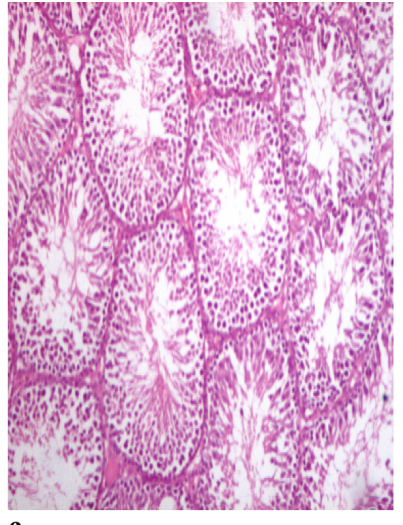

c

Figure (1): Representative micrographs for normal histo-pathological findings in control rats showing; (a) normal hepatic portal tract with potal artery, portal vein (double headed arrows) and bile ducts (arrow)x400, (b) kidney: normal proximal convoluted tubules (arrow)and glomeruli(double arrows) x 200 and (c) normal testes showing normal spermatogenesisx 100.
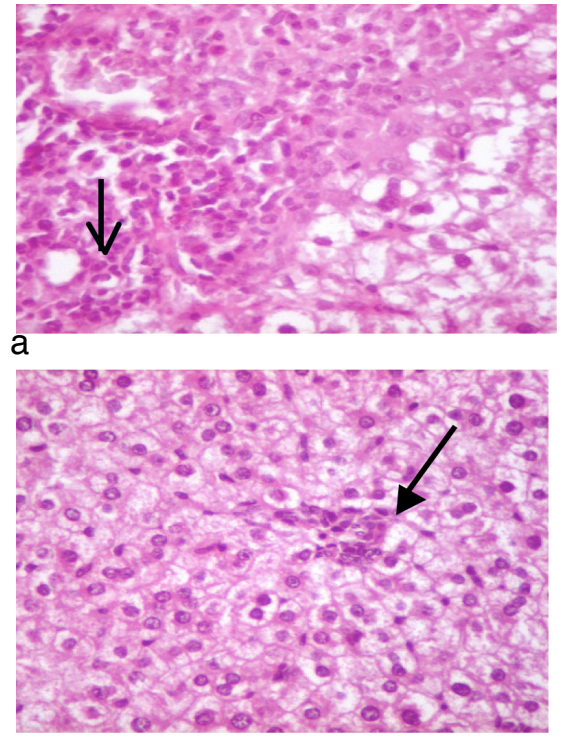

b
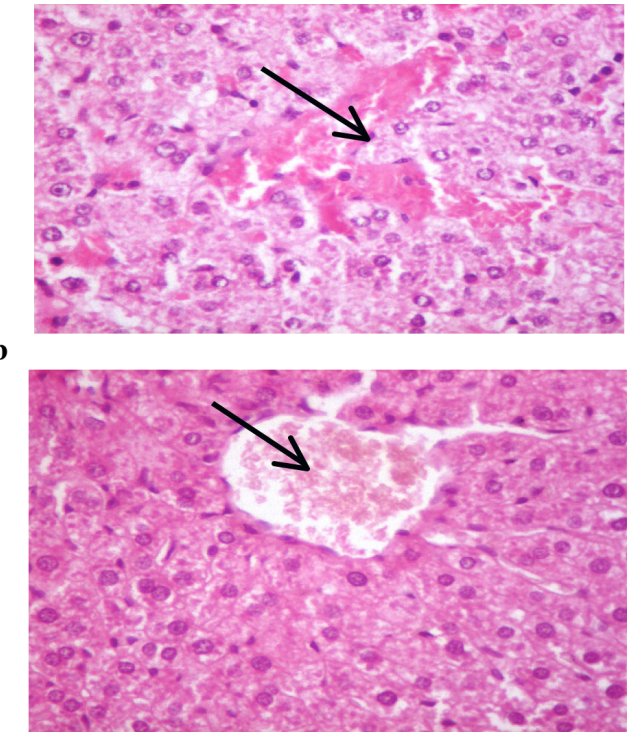

d

Figure (2): Representative micrographs for some histopathological changes in the liver of cypermethrin -treated animals showing; (a) portal inflammation showing lymphocytic and esinophilic infiltrates to the left of figure with atrophy of bile ductules (arrow)x400, (b) disorganization of hepatic lamina and congested sinusoids and prominent Von kupffer cells (arrow) x400, (c) spotty necrosis which is a small collection of lymphocytes (arrow) x400 and (d) normal structure 2 weeks after cessation of cypermethrin administration showing central vein (arrow) and normal single cell thick of liver cell cords $\mathrm{x} 400$.

Vol. 43, No. 1 \& 2 Jan. \& April, 2014 


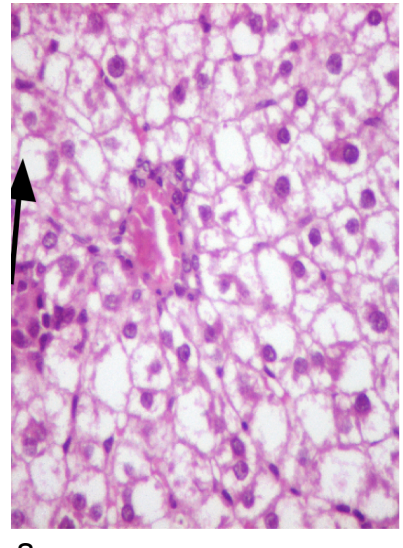

a

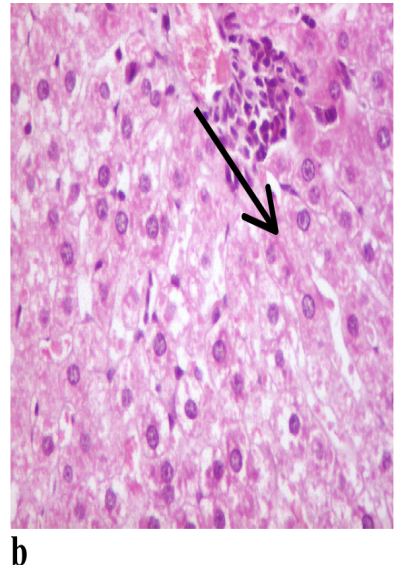

b

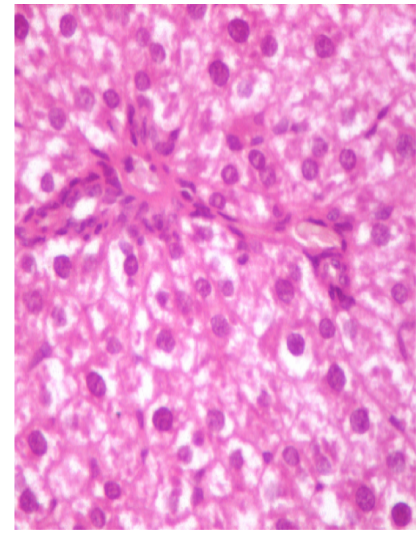

c

Figure (3): Representative micrographs for some histopathological changes in the liver of methomyl-treated animals showing; (a) ballooning degeneration (swollen hepatocytes with vacuolated and clear cytoplasm) and focal spotty necrosis (arrow) x400, (b) spotty necrosis (arrow) x400 and (c) normal structure 2 weeks after cessation of methomyl administration $\mathrm{x} 400$.
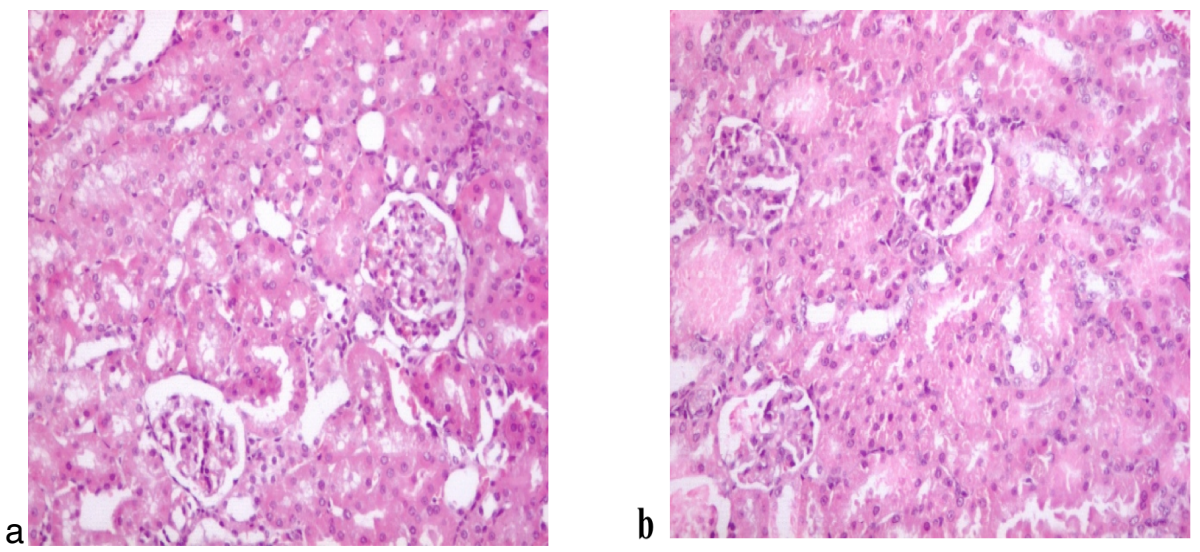

Figure (4): Representative micrographs for normal glomeruli and proximal convoluted tubules in the kidney of; (a) cypermethrin - treated animals x 200 and (b) methomyl - treated animals x 200 . 

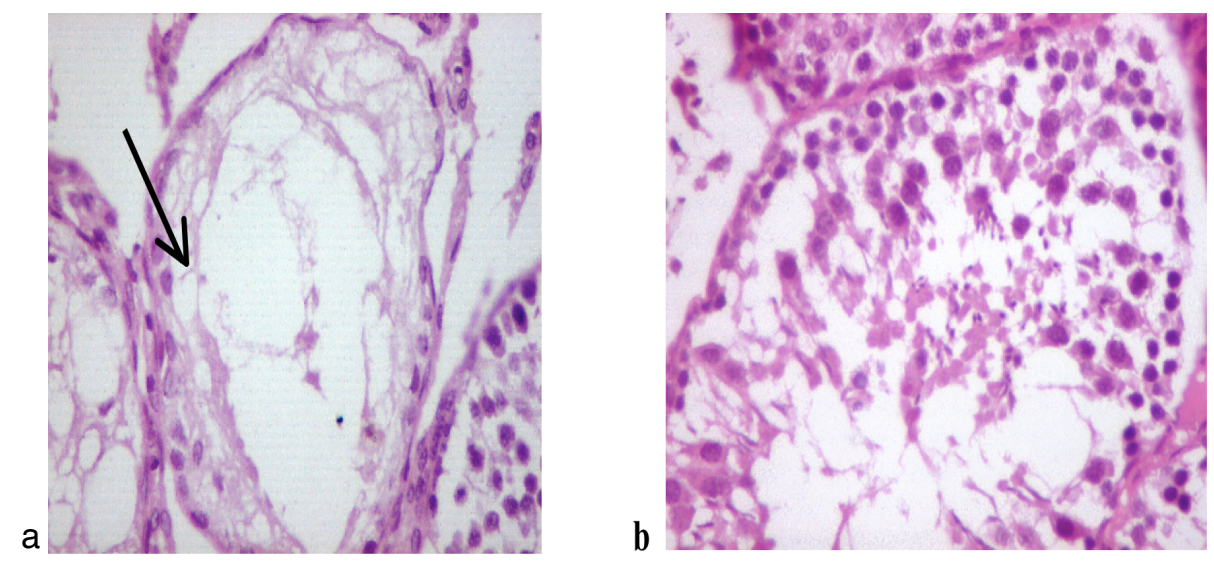

Figure (5): Representative micrographs for some histopathological changes in the testes of cypermethrin -treated animals showing; (a) maturation arrest at spermatogonia with only spermatogenic cells above a thick basement membrane (arrow) $\mathrm{x} 400$ and (b) showing restoration of normal spermatogenesis 2 weeks after cessation of cypermethrin administration $\mathrm{x} 400$.
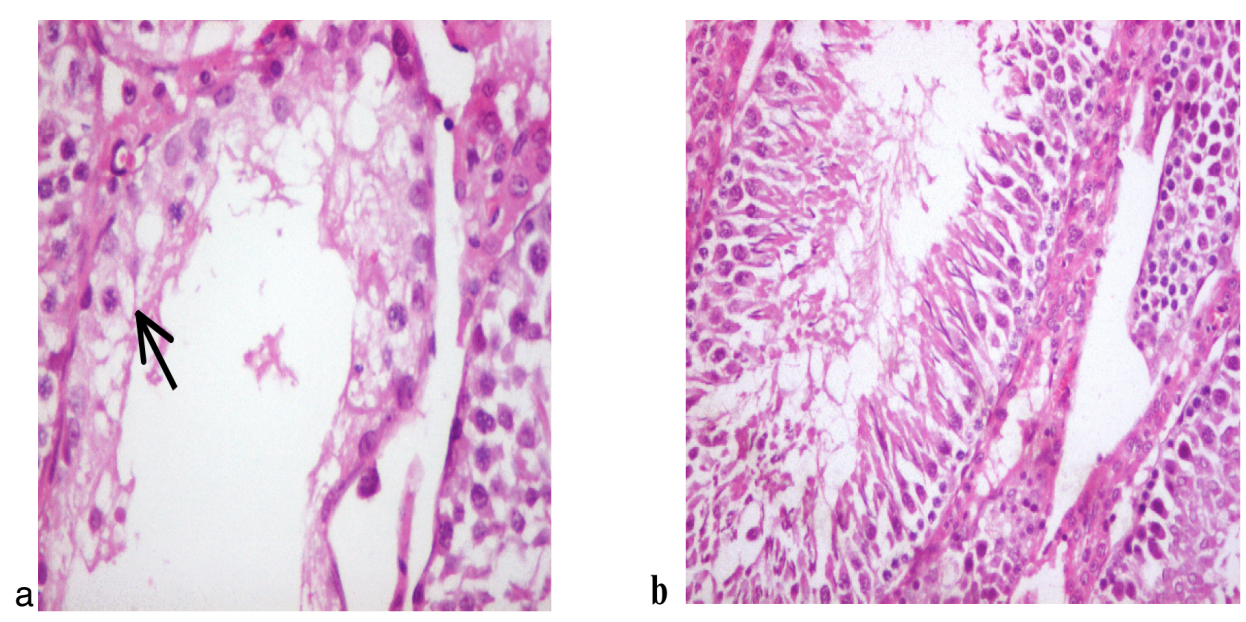

Figure (6): Representative micrographs for some histo-pathological changes in the testes of methomyl-treated animals showing; (a) maturation arrest at primary spermatocytes (arrow) $\mathrm{x} 400$, and (b) showing normal spermatogenesis 2 weeks after cessation of methomyl administration x 200 .

Vol. 43, No. 1 \& 2 Jan. \& April, 2014 


\section{DISCUSSION}

The non-controlled use of pesticides gives rise to various health related problems. The majority of these chemicals tend to accumulate in environment and enter into the food chain (7). The results of the present study showed that oral dose of both cypermethrin $(1 \mathrm{mg} / \mathrm{kg})$ and methomyl $(5 \mathrm{mg} / \mathrm{kg}$ ) for one month induced reversible toxic effects on liver, kidney and testis.

In the present research, both cypermethrin and methomyl did not induce any clinical manifestation on rats. It seems that due to the relative low dose used for both cypermethrin and methomyl in the present research, clinical toxic effects were not observed as higher oral doses were reported to induce mild to moderate toxicity $(4,8)$. Nevertheless, both pesticides decreased animals' weight gain as previously reported $(4,9,10)$. However, this effect was more significant by methomyl and improved significantly 2 weeks after cessation of administration.

Both cypermethrin and methomyl significantly increased AST and ALT. Similar results were reported $(11,12)$ although dose and duration of expo- sure differ. High serum AST, ALT induced by cypermethrin and methomyl were closely parallel to histopathological liver damage. Similar histopathological toxic effects on the liver were reported for cypermethrin $(4,9,13,14)$ and for methomyl (15, 16) however, the dosage and route of administration were different. Toxic effects of cypermethrin on the liver could be due to oxidative stress induced during its metabolism in the liver via the hydrolytic ester cleavage by the cytochrome P-450 microsomal enzyme system $(1,17)$. This is augmented by cypermethrin induced lipid peroxidation (18) and improvement of these toxic effects by antioxidants as vitamin C (19). Hepatotoxic effects of methomyl on the liver may be due to oxidative stress (20) or vascular changes particularly in the portal vessels (16).

While, Abdel Aziz and Zabut (21) reported spontaneous improvement in liver enzymes after cessation of methomyl administration to rats, in the present work, spontaneous improvement in hepatic histopathological damage induced by either cypermethrin or methomyl was not accompanied by normal AST or ALT levels. In their research, methomyl 
was administered for only five days, a relatively short period compared to the present research. Another explanation is the poor correlation of ALT serum levels and hepatic histopathological findings as previously reported for ethanol-induced liver injury in both human (22) and rats (23). In the same time, some other toxins have been reported to increase serum ALT with no histopathological liver finding (24).

In the present study both cypermethrin and methomyl significantly increased serum creatinine level (more in the methomyl group) in spite of the non observable histopathological changes in the kidney. It seems that at the used dose, both cypermethrin and methomyl induced cellular dysfunction manifested by increased creatinin but not severe enough to be seen by light microscope. Elevated creatinine is correlated with increased protein catabolism being its end product $(11,25)$. However, serum creatinine level improved significantly after cessation of cypermethrin more than methomyl. While spontaneous reversibility of elevated serum creatinine induced by cypermethrin was not reported before, reversible increase in serum creatinine induced by methomyl augments previous report by Fayez and Bahig (15) and Abdel Aziz and Zabut (21).

Lukowicz-Ratajczak and Krechniak (26) failed to prove any nephrotoxic effect of cypermethrin, while Grewal and colleagues (4) could. Meanwhile, cypermethrin $(5 \mathrm{mg} / \mathrm{kg} /$ day for 30 days) induced only mild sloughing off renal tubular epithilium with no effect on glomeruli, higher doses (20 mg/kg/day for 30 days) induced mild shrinkage of glomeruli, necrosis of renal tubules as well as hemorrhage and sloughing off renal epithelial cells in the convoluted tubules in rats; these effects were attributed to oxidative stress (27). At the cellular level, Luty et al. (28) demonstrated that dermally applied high dose of cypermethrin $(250 \mathrm{mg} /$ $\mathrm{kg}$ i.e. 1/2 LD50 for dermal application) to rats induced considerable number of autophagocytic vacuoli of renal proximal tubules, widened endoplasmic reticulum and widened Golgi apparatus as well as swollen mitochondria.

For methomyl, severe nephrotoxic effects were reported in rats (2 $\mathrm{mg} / \mathrm{kg}$, 3 times weekly for 3 months)

Vol. 43, No. 1 \& 2 Jan. \& April, 2014 
and in mice $(1 \mathrm{mg} / \mathrm{kg}$, for 20 and 30 days) by Radad et al. (16) and ElDemerdash et al. (27) respectively that was thought to be due to oxidative stress (30). Absence of histopathological toxic effects of methomyl on the kidney in the present work may be due to relatively lower dose (1 mg/kg once daily) and relatively shorter duration (only 30 days).

Reversible toxic effects of methomyl on testis found in the present study augment previous studies by Radad et al. (16) and Shalaby et al. (5). On the other hand, higher doses (17 mg kg) daily for 2 months induced persistent toxic effects on rat testes (31). Cypermethrin as 30 and $60 \mathrm{mg} / \mathrm{kg} /$ day induced severe testicular damage while slight distortion of seminiferous tubules was reported at $7.5 \mathrm{mg} / \mathrm{kg} /$ day. This testicular damage was attributed to testosterone disruption effect (32).

In conclusion, both cypermethrin and methomyl were found to be potentially toxic to liver, kidney and testes when administrated daily for $30 \mathrm{~d}$ at a dose of $5 \mathrm{mg} / \mathrm{kg}$ and $1 \mathrm{mg} /$ $\mathrm{kg}$ respectively. However, methomyl was found to be more toxic on the kidney. The observed hepatic, renal and testicular damage could predispose to hepatic insufficiency, renal failure and impaired fertility in exposed individuals. The spontaneous reversibility of toxic signs of both insecticides on cessation of exposure ensure that continued emphasis should be given to the correct handling and use of these insecticides at the recommended rates, dose and duration. Observations on regularly exposed workers should be maintained. These compounds must be used only where necessary and special precautions should be followed to avoid environmental over exposure. Further investigation is needed for longer durations to know if these effects are completely reversible or not.

\section{REFERENCES}

1. Dahamna $S$, Belguet $A$, Bouamra D, et al. (2011) : Evaluation of the toxicity of cypermethrin pesticide on organs weight loss and some biochemical and histological parameters. Commun. Agric. Appl. Biol. Sci.; 76 (4):915-921.

2. Farré $M$, Fernandez $J$, Paez $M$, et al. (2002) : Analysis and MANSOURA MEDICAL JOURNAL 
toxicity of methomyl and ametryn after biodegradation. Analytical and Bioanalytical Chemistry.; 373: 704-709.

3. Ibitayo OO. (2006) : Egyptian farmers' attitudes and behaviors regarding agricultural pesticides: implications for pesticide risk communication. Risk Analysis., 26: 989- 995.

4. Grewal KK, Sandhu GS, Kaur R, et al. (2010) : Toxic impacts of cypermethrin on behavior and histology of certain tissues of albino rats. Toxicol. Int.; 17:94-98.

5. Shalaby MA, El Zorba HY, Ziada RM. (2010) : Reproductive toxicity of methomyl insecticide in male rats and protective effect of folic acid. Food Chem Toxicol., 48(11):3221-3226.

6. Iyaniwura TT, Okonkwo, CA. (2004) : The acute intraperitoneal toxicity of cypermethrin. Vet. Hum. Toxicol.; 46(2):91-92.
7. Abhay SY, Gulshan S. (2011) : Evaluation of Genetic Damage in Farmers Exposed to Pesticide Mixtures. Int. J. Hum. Genet.; 11(2): 105109.

8. Mokhtar HI, Abdel-Latif HA, El Mazoudy $\mathrm{RH}$, et al. (2013) : Effect of methomyl on fertility, embryotoxicity and physiological parameters in female rats. Journal of Applied Pharmaceutical Science.; 3 (12): 109-119.

9. Nair RR, Abraham MJ, Lalithakunjamma CR, et al. (2011) : Pathomorphological study of the sublethal toxicity of cypermethrin in Sprague Dawley rats. Int. J. Nutr. Pharmacol. Neurol. Dis.; 1:179-183.

10. Sangha GK, Kaur K, Khera KS, Singh B. (2011) : Toxicological effects of cypermethrin on female albino rats. Toxicol. Int.; 18(1): 5-8.

11. Grewal G, Verma PK, Dhar V, 
Srivastava AK. (2009) :

Toxicity of subacute oral administration of cypermethrin in rats with special reference to histopathological changes Int. J. Green Pharm.; 3: 293-299.

12. Nair RR, Abraham MJ, Nair ND. (2010) : Lalithakunjamma CR, Aravindakshan $\mathrm{CM}$. Hemtological and biochemical profile in sub lethal toxicity of cypermethrin in rats. Int. J. Biol. Med. Res.; 1(4): 211-214.

13. Yavasoglu A, Sayim F, Uyamkgil Y, et al. (2006) : The pyrethroid cypermethrin induced biochemical and histological alterations in rat liver. J. Health Sci.; 52:774-780.

14. Muthuviveganandavel $\mathrm{V}, \mathrm{Mu}-$ thuraman $\mathbf{P}$, Muthu $\mathrm{S}$, Srikumar K. (2008) : A study of low dose cypermethrin induced histopathology, lipid peroxidation and marker enzyme changes in male rat. Pestic. Biochem. Physiol.; 91:12-16.
15. Fayez V, Bahig MRE. (1991) : Short term toxicity of methomyl in rats. Chemosphere.; 23 (3): 375-381.

16. Radad $K$, Hashim A, ElSharqawy EEG, El-Din Youssef MS. (2009) : Histopathological effects of methomyl on SpragueDawley rats after repeated application. Bulg. J. Vet. Med.; 12 (2): 149-157.

17. Khan A, Faridi, HA, Ali M, et al. (2009) : Effects of cypermethrin on some clinico- hemato- biochemical and pathological parameters in male dwarf goats (Capra hircus). Exp. Toxicol. Pathol.; 61:151-160.

18. Raina R, Verma PK, Pankaj NK, Prawez S. (2009) : Induction of oxidative stress and lipid peroxidation in rats chronically exposed to cypermethrin through dermal application. J. Vet. Sci.; 10 (3):257-259.

19. Assayed ME, Khalaf AA, Salem HA. (2010) : Protective MANSOURA MEDICAL JOURNAL 
effects of garlic extract and vitamin $C$ against in vivo cypermethrin-induced cytogenetic damage in rat bone-marrow. Mutat. Res.; $30 ; 702(1): 1-7$.

20. Banerjee BD, Seth V, Bhattacharya A, et al. (1999) : Bio-chemical effects of some pesticides on lipid peroxidation and freeradical scavengers. Toxicology Letters.; 107, 33-47.

21. Abdel Aziz I, Zabut B. (2014) : Alterations of blood indices associated with low-dose administration of methomyl insecticide for short times to albino Rats. Egyptian Journal of Biology.; (16):17-23.

22. Yin $M$, Wheeler MD, Kono $H$, et al. (1999) : Essential role of tumor necrosis factor $\alpha$ in alcohol-induced liver injury. Gastroenterology.; 117: 942-952.

23. Ronis MJ, Butura A, Sampey BP, et al. (2005) : Effects of $\mathrm{N}$-acetylcysteine on eth- anol-induced hepatotoxicity in rats fed via total enteral nutrition. Free Radical. Biol. Med. 2005; 39 (5):619-630.

24. Wang T, Papoutsi M, Wiesmann M. et al. (2011) : Investigation of correlation among safety biomarkers in serum, histopathological examination, and toxicogenomics. Int. J. Toxicol. 2011; 30(3):300-312.

25. Saxena $P$, Saxena AK. (2010) : Cypermethrin Induced Biochemical Alterations in the Blood of Albino Rats. Jordan Journal of Biological Sciences. 2010; 3(3): 111-114.

26. Lukowicz-Ratajczak J, Krechniak J. (1991) : Effect of decamethrin and cypermethrin on kidney function and metabolism. Bromat Chem Toksykol.; 24: 133137.

27. Sakr SA, Albaraka AY. (2014) : Effect of cinnamon on cypermethrin-induced neph- 
Mona A El-Harouny et al...

rotoxicity in albino rats. International Journal of Advanced Research.; 2(7): 578-586.

28. Luty S, Latuszyriska J, Halliop J, et al. (1998) : Toxicity of dermally applied alpha-cypermethrin in rats. Ann. Agric. Environ. Med. 1998; 5:109-115.

29. El-Demerdash F1, Dewer Y, El-Mazoudy RH, Attia AA. (2014) : Kidney antioxidant status, biochemical parameters and histopathological changes induced by methomyl in CD-1 mice. Exp Toxicol Pathol. 2014; 65 (6):897-901 .

30. Djeffal A, Messarah M, Bou- mendjel A, Kadeche L, Feki AE. (2015) : Protective effects of vitamin $C$ and selenium supplementation on methomyl-induced tissue oxidative stress in adult rats. Toxicol Ind Health.; 31(1):31-43.

31. Mahgoub AA, El-Medany AH. (2001) : Evaluation of chronic exposure of the male rat reproductive system to the insecticide methomyl. Pharmacol Res.; 44 (2):73-80.

32. Fang LY, Chen PAN, Xia HJ, et al. (2013) : Effects of cypermethrin on male reproductive system in adult rats. Biomed. Environ. Sci.; 26 (3): 201-208. 


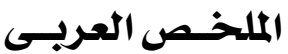

\author{
التأثيرات السمية للسايبـرمثرين والميثوميل فى الجرذان \\ أ.د. منى الحارونى* .د. سحر الدكرورىى \\ أ.د. آمال البقرى** د. رحاب اللّه أحمد \\ من قسمى الطب الشرعى والسموم الإكلينيكية * ، \\ والباثولوجى** - كلية الطب - جامعة المنصورة.
}

المبيـات هى مواد أو خليط من مـواد و التى مـا زالت تستخلدم بفاعلية للقضاء على الحشرات و

لذلك فان الاستخدام الواسـع للمبـيدات فى الإنتاج الزراعى والحيوانى يمكن أن يؤدى إلى مـخاطر صـحيـة مـحـتمـلـة. ومن ثم فقـد هـدفت هـذه الدراسـة لمقـارنـة تأثيـرات الجـرعات تحت السـمـيلة مـن السـايبـرمـثرين والميثوميل على الجـرذان والتحقق من إمـكانيـة تحسن هـذه الآثار بعد التوقف عن

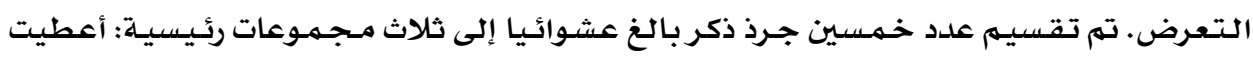
المجموعة الأولى (·r جرذ) السـايبـرمثرين ه مجم / كجم يوميـا عن طريق الفمه، المجموعة الثانية

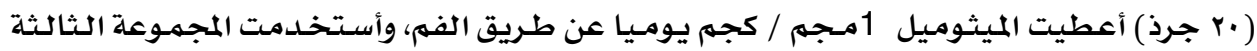

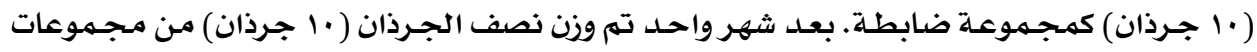
الاختبـار (المجموعة 1aوالمجموعة 2a) و المجمـوعة الضسابطة ثم ذبحهم. وظل النصف الآخر دون علاج لمدة أسبوعين ثم تم وزنها وذبحها (المجمهوعة 1b والمجموعة 2b. تم تحليل أنزيهات الكبد والكـريـاتينـين. وتم إجـراء فحص هستوبـاثولـوجى للكبـد والكلى والخصيتـين لكل الجـرذان. وقد أظهرت النـتائج أن كلا من الميثومسيل والسايبـرمثرين له تأثيـر سام على الكبد والكلى والخصيتين. وعلى الرغمم من المعـروف عن المبـيـات البـيـريثريـنيـة أنها أقل سـميـة على الثديـيـات من المبـيدات الاخـرى، فقد كشفت هـذه الدراسـة أنها يهكن أن تؤثر على مختـلف الأجهزة الحـيويـة فى الجسهم

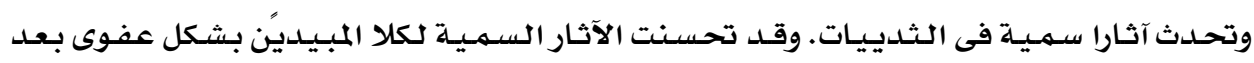
أسبوعـين مـن وقف التعرض. وبـالتـالى فإن تقنـين مدة التعرض عـامل ذو قيـمـة يـنبـفى أن يؤخذ فى الإعتبار أثناء إستخدام هذه المبيدات.

Vol. 43, No. 1 \& 2 Jan. \& April, 2014 